\title{
Major editorial changes of Romanian Review of Laboratory Medicine
}

\section{Modificări majore în redacția Revistei Române de Medicină de Laborator}

\author{
Adrian Man ${ }^{1}$, Cosmin Moldovan², Minodora Dobreanu ${ }^{3}$ \\ University of Medicine and Pharmacy, Tîrgu Mureş, \\ 1. Department of Microbiology, 2. Department of Histology, 3. Department of Laboratory Medicine
}

\begin{abstract}
Starting with the first issue of 2013, the Romanian Review of Laboratory Medicine has implemented a new editorial and publishing system. By this editorial, we try to clarify to all the readers and authors the major changes and their outcome in the journal's evolution. Thus, we present details related to the current internal organization of the editorial board and the editorial workflow of the submitted manuscripts.
\end{abstract}

Keywords: editorial policy, editorial workflow, scientific review, publishing

\section{Rezumat}

Începând cu primul număr din 2013, Revista Română de Medicină de Laborator a implementat un nou sistem editorial şi de publicare. În cadrul acestui editorial vom încerca să clarificăm pentru toți cititorii şi autorii schimbările majore şi efectul lor asupra evoluției revistei. Astfel, vom prezenta detalii legate de organizarea internă actuală a comitetului redacțional şi fluxul de lucru în redacție a articolelor trimise spre publicare.

Cuvinte cheie: politică redacțională, flux redacțional, recenzie ştiințificăă, publicare

Received: $30^{\text {th }}$ November 2013; Accepted: $5^{\text {th }}$ December 2013; Published: $11^{\text {th }}$ December 2013.

\section{Introduction}

Romanian Review of Laboratory Medicine has undergone major editorial changes during the last six months, bringing about a new strategy and vision. One of our main mission statements is to improve the quality of the papers published in the Journal and to become indexed and cited in relevant literature databases. From August 2013 on, the editorial process of our journal is assisted by Editorial Manager ${ }^{\circledR}$ (www.editorialmanager.com), a professional online submission system used by more than 4000 journals and hundreds of publishers, including Elsevier and Springer. Editorial Manager ${ }^{\circledR}$ allows authors, reviewers, and editors to perform their work from any computer with web access and is a useful tool in integrating the journal with abstracting and indexing databases, and in promoting it via Internet to researchers.

Starting with the first issue of 2013, the Romanian Review of Laboratory Medicine 
(RRLM) has implemented major changes in the editorial policies and procedures, although the workflow of the editorial process remained primarily the same. This was necessary in order to rigorously assure the editorial principles suggested by International Committee of Medical Journal Editors (ICMJE) and Committee on Publication Ethics (COPE): maximum transparency regarding the workflow of a submitted article (editorial process), editorial independence, confidentiality, responsiveness to complaints and criticisms $(1,2)$. These changes were and are presently publicly shared via the RRML website (in the form of instructions for authors, front page news and Rich Site Summary RSS feeds) and via the publisher's web site $(3,4)$, so the authors can permanently be up to date.

At the time of this editorial the journal owner has contracted a $3^{\text {rd }}$ party publisher, represented by Versita ${ }^{\circledR}$ (www.versita.com). The new copyright assignment is governed by Creative Commons rules, under "Noncommercial" and "No Derivative" conditions (permission to others to copy, distribute and transmit unaltered copies of the published article, but not for commercial purposes), and allows the Author to retain the proprietary rights related to the article $(5,6)$.

\section{Internal organization}

The editorial board of RRLM consists in several editor positions, hierarchically structured: editorial administration (Editor-in-chief, Deputy Editor, Editorial Office) and executive editorial committee (Technical Editor, Editorial Assistants and Editors). Each editor position has its specific function within the editorial board.

The Editor-in-chief verifies thematic correspondence with the journal domain classifications, validity of the work and its importance to readers, the accuracy and importance of journal articles, protection and strengthen the integrity and quality of the journal and its processes. The Editor-in-chief is conducting all the journal editorial activity: editor assignment, de- velopment of editorial staff, is keeping the editors updated with the new information on publishing, has authority over the editorial content and is responsible for the final decisions on submitted publications.

The Editorial Office takes note of every new submission, represents the main form of contact with the authors and the public, and is entitled to keep all the editing-related evidences (monthly/yearly internal statistics, the copyright assignment forms). Secretaries check if manuscripts are prepared in conformity to the "Uniform Requirements for Manuscripts Submitted to Biomedical Journals" issued by the International Committee of Medical Journal Editors (www.icmje.org).

The Technical Editor, or the website/research integrity editor, is responsible for public relations and news dissemination, as well as for various aspects of scientific misconduct, primarily by source scanning of submitted papers.

The Editorial Assistants, together with the Technical Editor, are assigned for the preliminary check of a new submission, assessing quality of writing and proper usage of statistical tests. A submission that does not correspond to or has any issues with any of these basic requirements will be sent back to author and will not enter into the editorial process.

\section{Editorial workflow}

The editorial workflow (Figure 1) is automatically conducted by the Editorial Manager® online system, which directs all the necessary steps, from the article submission to the final decision. Currently, the Authors must submit their manuscripts via the Editorial Manager ${ }^{\circledR}$ system (7). The system ensures total transparency and backtracking capability of the editorial process.

\section{Similarity matching}

Scientific misconduct is evaluated by similarity checking of every submission admitted for scientific evaluation. We follow the guidelines presented in a previous published statement on plagiarism "Publish or Perish vs. 


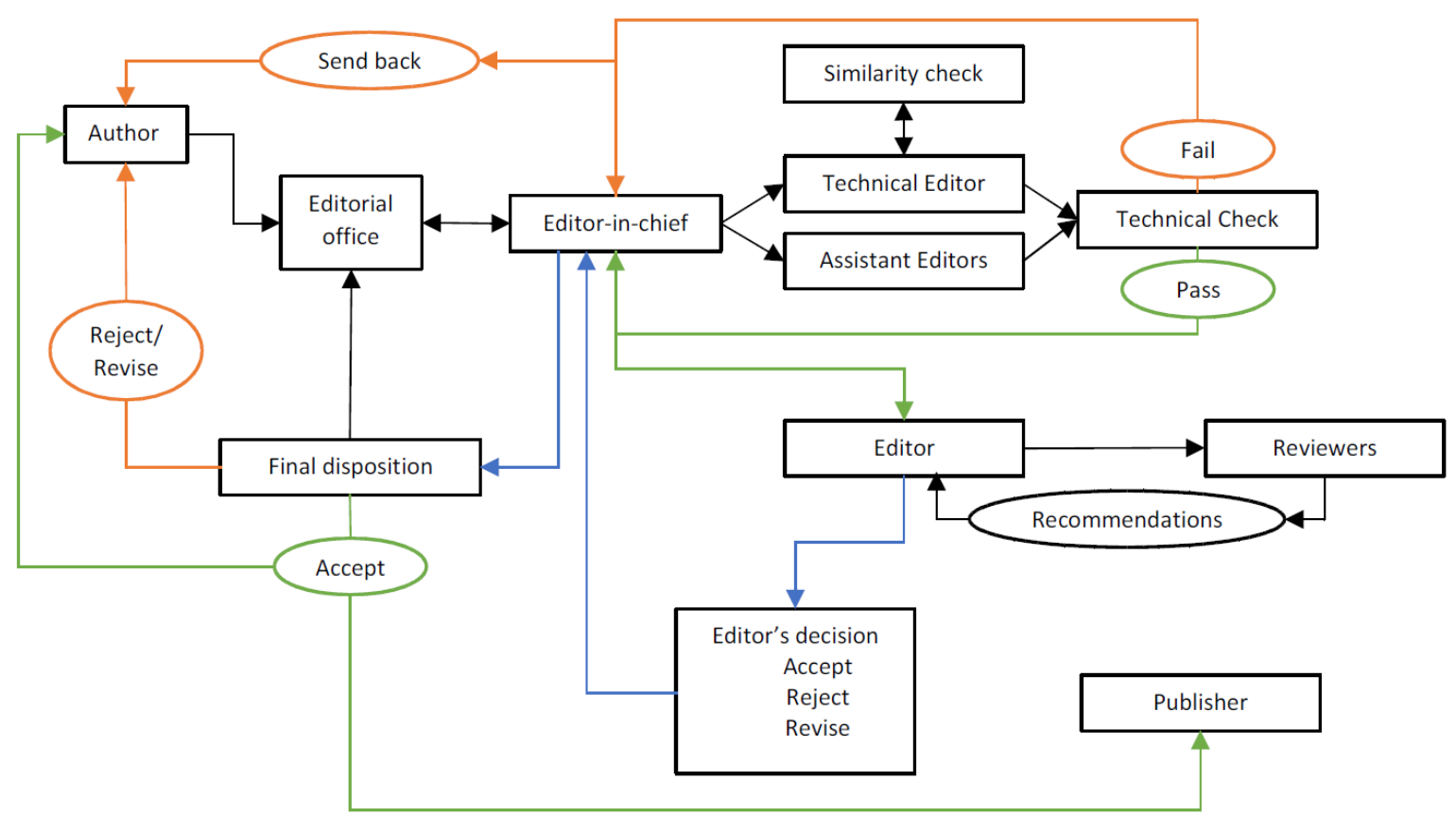

Figure 1. Workflow of the editorial process

Publish and Perish" (8). We are currently using CrossCheck®, a worldwide used similarity checking service with over 400 direct members and publishers (9), which claims that "Although there are several plagiarism screening tools already available, they are not well-suited to filtering academic content simply because they haven't had access to the relevant full-text literature to screen against. CrossCheck changes this by creating and continuously growing a database of current and archival scholarly literature" (10). We decided to exclude from similarity count the sources containing under 20 words, based on total match to a source, respectively the matches that are less than 10 concatenated words. This gives us a more real view on the plagiarism suspicion, as many unfiltered checks reported a similarity of over $25 \%$ but, when filtered, the percentage decreased to 10 $15 \%$. This is because many phrase fragments are non-medical related expressions, linking words, or complex medical terms, which falsely contribute to the similarity score. Moreover, a high similarity score does not necessarily constitute plagiarism, so a better interpretation of the score is being conducted by the editors, considering the article type, number of small matches, or areas within the article where similarities are highlighted.

Technical checking, editor assignment and reviewing process

Once the technical checking process is passed, the Editor-in-Chief assigns the submitted article to an Editor, according to the article's classification. If the article does not meet the minimum scientific requirements, as evaluated by the assigned editor, it will be rejected. Otherwise, the Editor will invite a minimum of 2 reviewers for the scientific evaluation of the article. We are using a closed peerreview system, so the reviewing process is double-blinded, as neither the author nor the reviewers have any information that can disclose their identity. However, COPE suggests that if a reviewing misconduct is suspected, it may be necessary to disclose that reviewer's name and/or the manuscript to a $3^{\text {rd }}$ party investigational committee (1). 
The scientific reviewer's critical assessment exerts the most powerful impact on the quality of manuscripts, and thus also on the journal. Their work is of a tremendous importance for the quality of articles published in Romanian Review of Laboratory Medicine and we are grateful for their efforts. The scientific assessment is quantified by the reviewers using an internal scoring system (11) and it is concluded as "Accepted", "Accepted with minor revision", "Accepted with major revision" or "Rejected", together with the comments to the Author. The Editor summarizes all the conclusions from all reviewers and notifies the Editor-in-Chief.

\section{The final disposition}

The final disposition is set by the Editor-in-Chief and it is announced to the Author via the online system.

\section{The publication}

An article that is accepted for publication will be sent to the publisher once the publication fee is paid by the Author. The articles can also be published to the RRML website and marked as "ahead-of-print" and "not for citation purposes", until the next issue is released. Starting with the first issue of 2013, all the published articles are assigned with DOI (Digital Object Identifier) numbers, as permanent links to the locations were the published articles can be found (current URLs).

The Romanian Review of Laboratory Medicine is committed to a continuous improvement, especially due and by the aid of digital era. The need for transparency, prevention of misconduct and smooth flow inside a journal editorial system are basic requirements nowadays, so we hope that through this approach we have managed to improve our position as a professional medical-related journal.
Disclosures. There are no disclosures related to this manuscript.

\section{References}

1. International standard_editors_for website_11_ Nov_2011.pdf [Internet]. [cited 2013 Nov 10]. Available from: http://publicationethics.org/files/International $\% 20$ standard_editors_for\%20website_11_Nov_2011.pdf

2. ICMJE: The New ICMJE Recommendations [Internet]. [cited 2013 Dec 1]. Available from: http://www.icmje.org/new_recommendations.html

3. Romanian Review of Laboratory Medicine / Versita [Internet]. [cited 2013 Nov 10]. Available from: http://versita.com/serial/romanian-review-of-laboratory-medicine/

4. Revista română de medicină de laborator [Internet]. [cited 2013 Dec 1]. Available from: http://rrml.ro/instructiuni_autori.php

5. license_to_publish.pdf [Internet]. [cited 2013 Nov 23]. Available from: http://rrml.ro/instr_autori/ license_to_publish.pdf

6. Creative Commons - Attribution-NonCommercial-NoDerivs 3.0 Romania - CC BY-NC-ND 3.0 RO [Internet]. [cited 2013 Nov 23]. Available from: http://creativecommons.org/licenses/by-nc-nd/3.0/ro/deed.en_US

7. Editorial Manager® [Internet]. [cited 2013 Nov 23]. Available from: http://www.editorialmanager.com/rrlm/ 8. Dobreanu M. Romanian Review of Laboratory Medicine Statement on plagiarism: Publish or Perish vs. Publish and Perish. Rev Romana Med Lab. 2012;20(3):193-7.

9. CrossCheck [Internet]. [cited 2013 Nov 10]. Available from: http://www.crossref.org/crosscheck_members.html

10. crossref.org: crosscheck [Internet]. [cited 2013 Nov 10]. Available from: http://www.crossref.org/crosscheck/ index.html

11. s22845623_Instructions_for_Reviewers.pdf [Internet]. [cited 2013 Dec 1]. Available from: http://www.degruyter.com/view/supplement/s22845623_Instructions_for _Reviewers.pdf 